\title{
The Attractiveness of Court Culture during the Jagiellonian Era
}

Court culture is generated predominantly by the social milieu surrounding the king and monarchic authority. The court guaranteed a suitable setting for all the activity of the monarch and royal accounts did not separate expenses for the private needs of the ruler and his family and those of a state character. The transmission of cultural values occurred everywhere where the king and court stayed: on the meadow where land court sessions were held, at the castle during a feast, at an assembly, in the course of a hunt, and along the entire route of the king's entourage. It should be kept in mind that the governance of Władysław II Jagiełło and his successors involved incessant motion, a constant traversing across Polish lands from Cracow to Lithuania. The image of the king viewed directly was connected in social mentality with a model of the monarch moulded by tradition and court ideology. This image was composed of two overlapping visions: the sacrum and the profanum. The former demanded respect for the God's anointed, and the latter rendered him closer to the perspective of the subjects and exposed him to criticism. ${ }^{1}$ Chronicles enable us seeing changes occurring in the ideology of power during the reign of the Piast dynasty. Casimir III the Great was already far from the image of the warrior-king and defender of the homeland depicted by Gallus writing about Bolesław I the Brave.

1 B. Kurbis, 'Sacrum i profanum. Dwie wizje władcy w polskim średniowieczu', Studia Źródtoznawcze, 22, 1977, p. 22. 
Janko of Czarnków emphasized the greatness and might of the last Piast ruler by stressing his economic activity. Royal majesty was additionally enhanced by opulent court ceremonies. The chronicler justified an account of the convention of 1363: 'Since he was regarded a magnificent king and wished to demonstrate the glory of his kingdom, he held a splendid feast in the town of Cracow'.2

In Janko's chronicle both elements: the sacrum and the profanum yield an image of Casimir III the Great; on the one hand, the chronicler provided a majestic description of the king's funeral and, on the other hand, he portrayed Casimir's illness and the helplessness of the physicians. Presumably, in the eyes of at least the enlightened part of society all royal undertakings were composed of those two elements. This attitude is legible also in the chronicle of Jan Długosz describing the activity of successive representatives of the Jagiellonian dynasty.

Such great court-state events as a coronation were obviously simultaneously 'spectacle and liturgy', but perhaps even more essential is the fact that other court ceremonies, for example entries, hunts, and feasts contained a double meaning. Travelling royal retinue was perceived by a worldly nobleman differently than by a humble cleric or a peasant who understood little of the court symbolic.

In his satire: De curie miseria, ${ }^{3}$ Mikołaj Oloch of Szamotuły, a fifteenth-century provincial cleric, criticised the incomprehensible and strange lifestyle, clothes, and customs of the court. He repeated various opinions since, he admitted, 'he never frequented the court'. Let us follow Mikołaj's traces and take a look at what he found so strange. First and foremost, he was outraged by the loss of the familiar order of the world. Courtiers did not observe the time of day and night, and often woke in the middle of the night and in the manner of madmen rushed off entrusted with the orders of their lord. They spent long idle hours, waiting in the antechambers to be summoned.

Oloch unconsciously touched upon the most important aspect - the fact that at court everything circulated around the monarch. The ruler even interfered in the natural rhythm of things and mingled time intended for entertainment and work, which overlapped within the court milieu. One may add that upon certain occasions time was forced to succumb

2 Ibid., p. 36.

3 'De curie miseria', ed. by R. Ganszyniec, Pamiętnik Literacki, 1927, p. 86. 
to the king: in 1370 Philip V of France ordered all Parisian clocks to be set according to a royal clock at the Louvre. ${ }^{4}$

Other information mentions also personal courtiers whose sole function consisted of entertaining. They included the court jester, ${ }^{5}$ a figure familiar from Byzantine and West European court structures, and appearing also in Poland. During the Early Middle Ages the jester belonged to the large group of 'itinerant people' supplying entertainment and including wandering histriones, ioculatores, mimes and fairground fools.

The jester enjoyed special rights - only he was permitted to tell the ruler the truth, even if unpleasant and malicious. To prevent the abuse of this privilege the jester wore a characteristic costume for the duration of fulfilling his function. ${ }^{6}$ His apparel, known from Polish and European iconography, was composed of a cap with flaps and sometimes decorated with a cockscomb, a brightly coloured jerkin adorned with bells, and a jester's sceptre, which Mikołaj Rej described as a cep (flail) owing to its mobile end. These clothes constituted a sui generis 'pass' permitting the jester to wander all over the court without fear of punishment. He enjoyed unlimited access to the ruler, and all courtiers feared his sharp wit. The typical feature of this profession was the fact that at late medieval courts the function of the jester was sometimes fulfilled by a nobleman. Mikołaj Twar, court jester at the time of Władysław II Jagiełło, was described as nobilis. A jester named Henne employed during the same period at the Lithuanian court of Duke Vytautas was a knight who in the morning brandished his sword and at noon changed clothes and entertained the duke's court with jokes and witticisms.

King Alexander I Jagiellon employed at Wawel Castle a jester-knight decades prior to the famous Stańczyk. This function, sometimes known as a wise man - sapiens, appeared also at the French court, where amidst common jesters one was distinguished by being called sage. Stańczyk was the best of several jesters at the court of Sigismund I the Old, and it is quite possible that the popularity and recognition he enjoyed in sixteenth-century Cracow were the reason why the function of the court

4 J. Le Goff, 'Od czasu średniowiecznego do czasu nowożytnego', in Czas w kulturze, Warsaw, 1988, p. 369.

5 M. Wilska, 'Le fou de cour: sa place dans la culture médiévale polonaise', Revue de la Bibliothèque Nationale, 42, 1991, pp. 2-10.

6 Ead., 'Strój błazna dworskiego u schyłku średniowiecza', in Biedni i bogaci, Warsaw, 1992, pp. 313-23. 
jester became common also at the courts of magnates. We know about the famous jester Jaśko at the court of Piotr Kmita, and Staś employed by the Boner family.

In 1492 there appeared at the court of King Jan Olbracht another curious person, that is, a dwarf, ${ }^{7}$ previously not encountered in Poland but familiar at the Teutonic Order court in Malbork as well as at Italian and French courts. In 1505 accounts kept by the court of Alexander I Jagiellon feature 2 florens paid for the dwarf Iwanko, ${ }^{8}$ whose name could testify to his Ruthenian origin; he might have been born in the Duchy of Lithuania since many persons suffering from such a deformity came from Samogitia. Some found themselves in Malbork and at the court of Duke Vytautas. The opinion that dwarfs first appeared in Poland in 1518 as members of the retinue of Queen Bona is, therefore, incorrect. ${ }^{9}$ The she-dwarf Maryna, a favourite of Bona, lived long and continued to receive a pension during the reign of Stephen Báthory.

The daughters of Sigismund I the Old, princesses Anna and Catherine, also had their she-dwarfs, while Barbara Radziwiłł employed a male dwarf known as Okuła or Okuliński. Princess Catherine was so attached to her dwarfs Dosia and Basia that she took them along to Sweden, where they shared her sad plight and were imprisoned together with the queen for four years at Gripsholm Castle. Dosia was educated and wrote letters containing information about Catherine to her sister, Sophia, the duchess of Brunswick. Contrary to his father, Sigismund II Augustus employed at court several dwarfs, male and female, who wore special shoes. This fashion became adapted at the courts of Lithuanian magnates and at the end of the sixteenth century also at Polish courts.

One of the curiosities of court culture was bestiaries. Accounts kept at the court of Jadwiga and Jagiełło for the 1388-1420 period, published by F. Piekosiński, mention the payment of a constant wage for Wojciech, keeper of the royal menagerie, who in 1389 received 'one grzywna or

7 Warsaw, Archiwum Główne Akt Dawnych (Central Archives of Historical Records; hereafter: AGAD), Rachunki królewskie, Book 20, 1. 71v.

8 AGAD, Rachunki królewskie, Book 34, 1. 60v.

9 W. Pociecha, Królowa Bona, vol. 2, Poznań, 1949, p. 46. Cf. also B. Fabiani, Niziotki, tokietki, karlikowie, Warsaw, 1980, p. 39. The author of this article also maintained that dwarfs did not appear at the Jagiellonian court until the arrival of Queen Bona. See M. Wilska, 'Osobliwości kultury dworskiej. Luksus czy potrzeba', in Nędza i dostatek na ziemiach polskich od średniowiecza po wiek XX, ed. by J. Sztetyłło, Warsaw, 1992, p. 21. 
two quarters'.$^{10}$ It follows from other documents that already during the reign of Casimir III the Great a royal bestiary was set up on Salwator near Cracow. A fenced in fragment of the forest in Niepołomice was used for keeping wild animals for the purpose of hunts. This was a typical feature of the late medieval courts in Europe. By way of example, in fifteenth-century France a menagerie was situated in the environs of the palace in the Cité; subsequently, Philip VI ordered it to be moved to the Louvre gardens. ${ }^{11}$

Importance was attached not only to the existence of a menagerie but also to its contents. Animals were granted a certain symbolic and included less and more worthy ones. During the Early Middle Ages the camel was regarded as a royal animal; this is why German chroniclers highly regarded the gift presented by Mieszko I to the German emperor. ${ }^{12}$

Prestigious, valuable and important animals included lions. In 1386 the Louvre employed a lion keeper who received the considerable sum of 48 livres a month. A letter preserved in the chancery of Władysław II Jagiełło, written almost at the same time by the council of the town of Florence (1406), informs that lions had been dispatched to Cracow (during the fourteenth century Florence was the chief exporter of lions to the whole of Europe). The letter also contains practical advise concerning the keeping of lions so that they would grow and multiply. ${ }^{13}$ Presumably, the recommendations were heeded since throughout the entire Jagiellonian era the royal menagerie continued to feature these animals. In 1547 a lion was also part of the Vilnius menagerie kept by the court of Sigismund II Augustus. ${ }^{14}$

Iconographic sources, whose peak examples include tapestries on display at Musée de Cluny today (the so-called The Lady and the Unicorn), depict castle interiors and gardens full of exotic animals, such as lions as

10 Rachunki dworu Wtadystawa Jagietty i królowej Jadwigi z lat 1388-1452, ed. by F. Piekosiński, Cracow, 1896, pp. 367, 562.

11 A. Franklin, La vie privée d'autrefois. Arts et métiers, modes, moeurs, usages des Parisiens du XII au XVIII siècle [...], vol. 20: Les Animaux, vol. 1, Paris, 1897, pp. 283-285, 317; vol. 24: Les Animaux, vol. 2, Paris, 1898, pp. 539, 541.

12 J. Banaszkiewicz, 'Mieszko I i władcy jego epoki', in Polska Mieszka I, Poznań, 1993, p. $93 \mathrm{ff}$.

13 Codex epistolaris saeculi decimi quinti, vol. 1, Cracow, 1876, pp. 25-26.

14 L. Kolankowski, Zygmunt August wielki książe Litwy do roku 1548, Lviv, 1913, p. 325 . 
well as birds: peacocks and parrots. Preserved accounts and inventories testify that these were not solely motifs of the artistic style of a given epoch but also a reflection of reality. Western sources provide exact lists of the kept birds: parrots, pelicans, nightingales, larks or siskins. Less extensive Polish documentation mentions that the situation at the local courts was similar. Books of Metryka mazowiecka from 1414-25 contain amongst entries pertaining to land grants or exchanges also a note about ways of keeping the parrot offered to Duke Janusz I, owner of Warsaw Castle. ${ }^{15}$ Apparently, the Mazovian court also followed universally accepted customs and fashion. A parrot was undoubtedly an exotic bird in Mazovia since no one knew how to take care of it.

Exotic birdhouses and menageries added enormous splendour to a court and produced extensive interest among the courtiers. This is why in the second half of the fifteenth century this custom, observed at the royal court, spread also to magnate courts. In 1478, Szafraniec, one of the advisers of Casimir IV Jagiellon, ordered that a parrot and a singing blackbird be kept at his castle and employed a special boy for this purpose. The blackbird died due to lack of suitable attention and the boy, fearing his master's anger, leapt out of a tower. ${ }^{16}$

The attractiveness of court culture involved gathering curious human beings and creatures within the milieu surrounding the king. In a satire ridiculing the courtly lifestyle the above-mentioned Mikołaj Oloch of Szamotuly derided also prevailing customs: 'The courtiers possess a multitude of words but openly lack a multitude of good habits' ${ }^{17}$ A sixteenth-century proverb: 'He who is courteous is also loquacious' 18 stressed the eloquence of the courtiers. Courtly customs also imposed a certain form of addressing women and behaviour towards them. The royal entourage and its circle produced a specific attitude towards ladies, who were the addressees of such lyrics as a poem about the Rose and May, probably written by Stanisław Ciołek (died in 1437), courtier and years-long employee at the chancery of Władysław II Jagiełło. Compositions of this sort were often recited to the accompaniment of music and intended for ladies-in-waiting at the court of Queen Sophia.

15 Marticularum Ducatus Masoviae codices saeculo XV-XVI conscripti, vol. 1: Liber distinctus numero 333 annorum 1417-1429, Warsaw, 1918 (Monumenta Iuris, 5), p. 127.

16 A. Brückner, Dzieje kultury polskiej, vol. 1, Warsaw, 1938, p. 435.

17 'De curie miseria', op. cit., p. 86.

18 J. Krzyżanowski, Mądrej gtowie dość dwie stowie, vols. 1-3, Warsaw, 1975. 
The increasingly extensive participation of women in court life was, as a rule, associated with a general change of the position held by women in society, influenced by, for instance, the dissemination of the Marian cult propagated also by the royal court. Courtesy towards ladies-in-waiting was frequently adopted by the gentry, as witnessed by a poem written in Great Poland by Słota, in which polite speech addressed to women is combined with respect due to the Holy Virgin Mary. The impact of culture affected also the literary language. Close contacts between Wawel Castle and Cracow University were the reason why forms accepted at the royal court spread all across Poland via students as well as formularies. Presumably, the emergence of various forms of politeness and respect for women was to a large degree influenced by the role played by Queen Jadwiga, who was not merely a representative of one of the most refined court milieus in Europe at the time but also an extraordinary personality. Her status, exceptional in Poland, offered an opportunity to exert an impact greater than in the case of other queens of the period. Jadwiga arrived from Hungary in the company of carefully chosen ladies-in-waiting, who proved to be attractive prospective wives for Polish magnates. One of them, from an unidentified family, married Stanisław Gamrat and received from the queen a dowry worth 150 grzywnas in return for her loyal service, personal culture, and 'pleasant conversations' ${ }^{19}$

A privileged place in the daily life of the court was held by music. ${ }^{20}$ In contrast to other social groups, music accompanied the daily passage of the retinue of the king and his family. The sound of trumpets preceded the king and announced his approach before the knights on horseback even came into view. The rank of the royal trumpeters was high, and we know that until the twelfth century the use of this particular instrument was one of the royal privileges. Not until 1295 did a castellanus from Biała receive in return for saving the life of Duke Bolesław II of Mazovia the right to sound a trumpet during a chase and in the army, and, as the document mentions, to play the instrument whenever he wished to enhance his splendour. As a rule, there were several or even more than ten trumpeters at the royal court, where they constituted an important part of the monarch's retinue and accompanied him even during Corpus

19 Kodeks dyplomatyczny Polski, vol. 3, Warsaw, 1885, no. 182.

20 M. Wilska, 'Miejsce muzyki w kulturze dworskiej', Sprawozdania Wydziatu Nauk o Sztuce, 109, 1991 (1992), pp. 11-17; see also E. Głuszcz-Zwolińska, Muzyka nadworna ostatnich Jagiellonów, Cracow, 1988. 
Christi processions. In 1451 Długosz wrote: 'This ceremony was even more opulent than usual since it was enhanced by the presence of the king. Zbigniew, the cardinal and bishop of Cracow, celebrated Holy Mass and carried the Most Holy Sacrament in a procession around the market square. Behind him walked King Casimir and Queen Sophia together with all the more prominent lords to the sound of trumpets'.$^{21}$ During the 1470s trumpeters were also part of magnate courts, for example, in 1478 Rożek, a trumpeter employed by Andrzej of Szamotuły, castellanus of Międzyrzec, played in front of the princes in Sandomierz and received one floren. Naturally, the court also employed a great variety of musicians, representatives of assorted nationalities. All members of the Jagiellonian dynasty had a special predilection for music. Differences occurred in the composition of the court orchestra: Jagiełło was particularly fond of Ruthenian performers, but at the time of Sigismund II Augustus Italian musicians predominated, for example, in 1547 musicians performing under a lute player included five lute players, seven trumpeters, two drummers and two musicians playing the harp. ${ }^{22}$ Following the example of the king and Polish magnates, Lithuanian lords also began to establish court orchestras. In 1547 a lute player of the voivode of Troki sang Lithuanian songs for King Sigismund.

Trumpeters together with flutists and violinists also performed during the course of meals held at a court. ${ }^{23}$ From the end of the fifteenth century dinners and suppers were partaken to the accompaniment of organs. During the sixteenth century this instrument was already played in numerous gentry homesteads, as mentioned by Mikołaj Rej. Organs are also featured in a woodcut to his Wizerunek cztowieka poczciwego. Rej, who, after all, was a courtier of King Sigismund and knew just how popular music at the royal court was, arrived there years later with his own company of musicians.

The extremely mobile and raucous court milieu also attracted attention due to its colourful appearance, clothes, and fashionably attired women. In this respect, the Jagiellonian court was by no means an exception. The fashion for colours, however, followed a course different from the rest

21 J. Długosz, Historiae Polonicae libri XII, vol. 5, Cracow, 1878 (idem, Opera omnia, 14), p. 84; ibid., vol. 6, p. 78 (transl. into Polish by M. Macherzyński).

22 AGAD, Rachunki królewskie, Book 120, 1. 18v.

23 AGAD, Rachunki królewskie, Books 29 and 33. 
of Europe. ${ }^{24}$ In early mediaeval Poland, as indicated by, for instance, the ambiguity of the word krasa, beauty was associated with an intense red colour. ${ }^{25}$ Red was also the most frequent colour of mediaeval armorial devices. ${ }^{26}$ Its popularity was the result of the fact that Slavonic countries used a local technique of obtaining dye from the larvae of an insect known as the Polish cochineal. Other shades of red known at the time included crimson and purple.

Mediaeval mentality and social reception connected red with great royal ceremonies, and the colour dominated in a combination with white and gold during coronations at which the king displayed the insignia of his power, a purple robe, sandals and gloves. The extant coronation sandals worn by Sigismund II Augustus in 1529 were made of purple velvet.

The ceremonial robes of dukes from the Piast dynasty in Silesia and Mazovia during the fifteenth century were modelled on royal coronation ceremonial dress and were composed of a purple robe lined or trimmed with ermine and embellished with gold, silver and precious stones, as well as red velvet gloves and a mitre. Golden Fleece Armorial from 1434-1435 (in Paris today) contains the ceremonial tournament costume of the Polish king: ${ }^{27}$ a purple tunic decorated with silver eagles wearing golden crowns. Purple is the caparison adorned with eagles and a red shield with a stylised eagle. The stately robes of the king were dominated by gold, silver and purple, colours that transmitted contents comprehensible for the entire society of mediaeval Poland and a visible sign of the monarch's power and valour. In France, by way of contrast, the coronation robes were predominantly blue.

Let us take a closer look at the history of the colour red in the light of court accounts showing the daily life of king and court. At the time of Jadwiga and Władysław II Jagiełło the ruler's clothes were chiefly grey

24 M. Wilska, 'Du symbole au vêtement. Fonction et signification de la couleur dans la culture courtoise de la Pologne médiévale', in Le vêtement. Histoire, archéologie et symbolique vestimentaires au Moyen Âge, Paris, 1989 (Cahiers du Léopard d'Or), pp. 307-25 (here pertinent literature on the topic).

25 T. Lalik, 'Poczucie piękna', in Kultura Polski średniowiecznej X-XIII wiek, ed. by J. Dowiat, Warsaw, 1985, pp. 375-423.

26 S. Mikucki, Barwa w heraldyce średniowiecznej, Warsaw, 1930.

27 A. Nadolski, 'Uroczysty strój rycerski królów polskich w XIV-XV wieku', Kwartalnik Historii Kultury Materialnej, 1973, pp. 305-18. 
and black. ${ }^{28}$ Great importance was attached to the shade of the black and the type of fabric. Hence, the jerkin made for Duke Vytautas in Cracow was black velvet, with accounts mentioning that it was sewn in the French style (modo gallico). High-ranking civil servants received Florentine, Flemish or Brussels cloth. Lower servants wore clothes made of locally produced cloth, but court musicians were granted colourful cloth.

During the reign of Władysław III of Varna red was combined with black. On the other hand, from the mid-fifteenth century the reign of Casimir IV Jagiellon ushered in the prevailing red. In 1471 ceremonial apparel was sewn for the whole court and retinue accompanying Prince Władysław to Prague, where he was to mount the Bohemian throne. Much was made in red while using various fabrics. The wedding of Hedwig, the daughter of Casimir IV Jagiellon, and Duke George of Bavaria took place in 1475. According to the chroniclers, the carriage of the princess was pulled by eight white horses whose harness was covered with red cloth and decorated with pearls. All the courtiers, even the pages leading the mounts, were dressed in red. The ladies-in-waiting of the princess attended the wedding also in red gowns. Descriptions of the princess' trousseau list numerous clothes of that colour. Court fashion became the reason why the trousseau of Princess Anna, who married Duke Bogusław $\mathrm{X}$, included a red velvet gown and two gilded carriages with red cloth interiors. Inventories of the dukes of Mazovia (1494) mention purple szubas (fur-lined coats) and mitres. ${ }^{29}$ Interestingly, the accounts of this court even list sewing eiderdowns made of red taffeta for the dukes.

At the end of the fifteenth century red became increasingly popular among magnate families, the civil servants, and the prosperous gentry. The dissemination of this fashion took place similarly as the transmission of other court customs. On the one hand, courtiers transferred customs observed at the royal court to their milieus and thus to other parts of Poland; on the other hand, a considerable contribution was made by the distribution of red cloth, for example from Florence. The spreading fashion for the colour red among the gentry was confirmed in the story of Stanisław Pleszewski. In 1464 this nobleman leased in Cracow his entire property, including a robe made of red velvet, a coat of red Florentine

28 K. Turska, Ubiór dworski w Polsce w dobie pierwszych Jagiellonów, Warsaw, 1967.

29 'Inwentarz skarbca książąt mazowieckich Konrada i Janusza z 1494 r.', ed. by J. Mycielski, Sprawozdania Komisji do Badań Historii Sztuki w Polsce, 8, 1907, 1-2, p. CLXI. 
cloth, a scarlet cap and purple gloves. At the turn of the fifteenth century the medium prosperous gentry adopted the fashion for red clothes and equipment. In the second decade of the sixteenth century court books from Warsaw mention thefts of a red saddle, red caps and shoes.

At the same time, at the court of Sigismund there appeared a new colour: blue, which started a fashion of its own. In 1538 the prices for blue fabric in Cracow became already higher than for red. From that time, blue was considered elegant and attractive due to its court provenance. Its popularity was enhanced by close Polish-Italian contacts at the time of Queen Bona. Moreover, from the end of the fifteenth century Poland witnessed a spreading Marian cult, and in iconography the Madonna almost always appears dressed in blue. What happened to the colour red? It remained popular in Polish folklore until the nineteenth century. Ethnographic research from that century indicates the extent to which this colour remained widely used in the Polish countryside. A string of red beads was an indispensable component of the peasant costume both in the lands of Cracow and Łowicz. According to folk songs collected by Oskar Kolberg every girl dreamed of possessing a pair of red shoes. ${ }^{30}$ This was the time when maidens of gentry origin wore blue gowns.

In this text I intended to show only selected aspects of the characteristic traits of court culture and its social reception. The Polish term dworność, corresponding to the Latin: curiositas, was recorded in 1429 in a manuscript from Lublin, and is cited in Stownik staropolski. ${ }^{31}$ Apparently, it is the most apt description of traits typical for the culture of this particular environment. In mediaeval Latin curiositas $^{32}$ is translated as: 1) curiosity, 2) secularity, 3) opulence, 4) witticism, joke. Written and iconographic sources indicate the syndrome of such court curiosity of the world in many different domains. This holds true both for interesting and strange people, animals, customs, and objects.

The development of particular branches of court culture was essentially affected by the individuality of the given ruler. By way of example, the musical inclinations of Władysław II Jagiełło and his predilection for icons could have influenced the progress of music and painting. Casimir III the Great created foundations for the organisation of the Polish royal

30 O. Kolberg, Przystowia polskie, 2nd ed., Warsaw 1977.

31 Stownik staropolski, ed. by S. Urbańczyk, vol. 2, Warsaw, 1956, p. 240.

32 Stownik taciny średniowiecznej $w$ Polsce, ed. by M. Plezia, vol. 2, Wrocław and Warsaw, 1959-67, p. 1515. 
court by emulating Hungarian models. Thanks to Jadwiga d'Anjou the court in Buda enabled French-Italian models to become a permanent part of the culture of the Jagiellonian court. At the beginning of the sixteenth century there was no difference in lifestyle in Cracow and Buda, as best seen in the accounts kept by the court of Prince Sigismund who resided successively in both towns. The culture of the Jagiellonian court also received additional impulses from Ruthenia and indirectly from Byzantium, which enhanced it even further. Take the example of the presence of icons and, for example, performances given by bear keepers.

At the end of the fifteenth century the court ceased acting as the sole centre of a transmission of new currents although the force of its impact was still enormous due to the social position of the monarch and his entourage. While discussing particular aspects of court life I cited examples of the transference of new phenomena at court to other social strata. Apparently, it was exactly this curiositas that proved decisive to a large extent for the attractiveness of court life, even more than wealth. Unusual people, animals and objects stirred curiosity, and that became in turn an impulse for emulation. It is precisely in the function of the dissemination of culture that the role played by the royal court was especially prominent.

Translated by Aleksandra Rodzińska-Chojnowska

First published as: 'Atrakcyjność kultury dworskiej w czasach Jagiellonów', Odrodzenie i Reformacja $w$ Polsce, 38, 1994, pp. 5-13. 